\title{
Whole-exome sequencing of Finnish patients with vascular cognitive impairment
}

\section{Mönkäre, Saana}

2021-04

Mönkäre , S , Kuuluvainen , L , Kun-Rodrigues , C , Carmona , S , Schleutker , J , Bras , J , Pöyhönen, M , Guerreiro , R \& Myllykangas , L 2021 , ' Whole-exome sequencing of Finnish patients with vascular cognitive impairment ' , European Journal of Human Genetics , vol. 29 , no. 4 , pp. 663-671 . https://doi.org/10.1038/s41431-020-00775-9

http://hdl.handle.net/10138/333907

https://doi.org/10.1038/s41431-020-00775-9

acceptedVersion

Downloaded from Helda, University of Helsinki institutional repository.

This is an electronic reprint of the original article.

This reprint may differ from the original in pagination and typographic detail.

Please cite the original version. 


\section{Whole-exome sequencing of Finnish patients with vascular cognitive impairment}

Saana Mönkäre, MSc, Department of Medical and Clinical Genetics, University of Helsinki, Helsinki, Finland and Turku University Hospital, Laboratory Division, Genomics, Department of Medical Genetics, Turku, Finland

Liina Kuuluvainen, MD, Department of Medical and Clinical Genetics, University of Helsinki, Helsinki, Finland and Department of Clinical Genetics, HUS Diagnostic Center, Helsinki University Hospital

Celia Kun-Rodrigues, MSc, Center for Neurodegenerative Science, Van Andel Institute, Grand Rapids, MI, USA

Susana Carmona, PhD, Center for Neurodegenerative Science, Van Andel Institute, Grand Rapids, MI, USA

Johanna Schleutker, PhD, Turku University Hospital, Laboratory Division, Genomics, Medical Genetics, Turku, Finland and Institute of Biomedicine, University of Turku, Turku, Finland

Jose Bras, PhD, Center for Neurodegenerative Science, Van Andel Institute, Grand Rapids, MI, USA and Division of Psychiatry and Behavioral Medicine, Michigan State University College of Human Medicine, Grand Rapids, MI, USA 
Minna Pöyhönen, MD, PhD, Department of Medical and Clinical Genetics, University of Helsinki, Helsinki, Finland and Department of Clinical Genetics, HUS Diagnostic Center, Helsinki University Hospital, Helsinki, Finland

Rita Guerreiro*, PhD, Center for Neurodegenerative Science, Van Andel Institute, Grand Rapids, MI, USA and Division of Psychiatry and Behavioral Medicine, Michigan State University College of Human Medicine, Grand Rapids, MI, USA

Liisa Myllykangas*, MD, PhD, Department of Pathology, University of Helsinki, Helsinki, Finland and HUS Diagnostic Center, Helsinki University Hospital, Helsinki, Finland

*These authors contributed equally to this work

Corresponding author: Liisa Myllykangas

University of Helsinki

POB 21

00014 Helsinki, Finland

tel. $+358-504482805$

E-mail. liisa.myllykangas@helsinki.fi

$\underline{\text { Running title: Exome sequencing of vascular cognitive impairment }}$ Tables 2; Figures 1. 


\begin{abstract}
Cerebral small vessel disease (CSVD) is the most important cause of vascular cognitive impairment (VCI). Most CSVD cases are sporadic but familial monogenic forms of the disorder have also been described. Despite the variants identified, many CSVD cases remain unexplained genetically. We used whole-exome sequencing in an attempt to identify novel gene variants underlying CSVD. A cohort of 35 Finnish patients with suspected CSVD was analyzed. Patients were screened negative for the most common variants affecting function in NOTCH3 in Finland (p.Arg133Cys and p.Arg182Cys). Whole-exome sequencing was performed to search for a genetic cause of CSVD. Our study resulted in the detection of possibly pathogenic variants or variants of unknown significance in genes known to associate with CSVD in six patients, accounting for $17 \%$ of cases. Those genes included NOTCH3, HTRA1, COL4A1, and COL4A2. We also identified variants with predicted pathogenic effect in genes associated with other neurological or stroke-related conditions in seven patients, accounting for $20 \%$ of cases. This study supports pathogenic roles of variants in COL4A1, COL4A2 and HTRA1 in CSVD and VCI. Our results also suggest that vascular pathogenic mechanisms are linked to neurodegenerative conditions and provide novel insights into the molecular basis of VCI.
\end{abstract}

Key words: cerebrovascular disorders, cerebral small vessel diseases, whole-exome sequencing, vascular dementia, vascular cognitive impairment 


\section{Introduction}

Vascular cognitive impairment (VCI) is a term used for cognitive impairment associated with cerebrovascular disease ${ }^{1}$. Vascular dementia $(\mathrm{VaD})$ is the most severe form of VCI and it is the second most common cause of dementia after Alzheimer's disease (AD) ${ }^{2}$. An important cause of VCI is cerebral small vessel disease (CSVD) which consists of a heterogeneous group of pathological processes that affect the small vessels of the brain ${ }^{3}$. Most CSVD patients suffer from a sporadic disorder but familial monogenic forms of the disorder have also been described ${ }^{4}$. CADASIL (cerebral autosomal dominant arteriopathy with subcortical infarcts and leukoencephalopathy) is the most frequent subtype of familial CSVD and is caused by variants affecting function in the NOTCH3 gene ${ }^{5}$. CARASIL (cerebral autosomal recessive arteriopathy with subcortical infarcts and leukoencephalopathy) is an autosomal recessive CSVD caused by pathogenic HTRA1 gene variants ${ }^{6}$, although an autosomal dominant form of the disease has been identified ${ }^{7}$. Autosomal dominant COL4A1-related CSVD is usually caused by pathogenic glycine missense variants within the triple helical domain of COL4A1/COL4A2 collagen genes ${ }^{8}$. Multi-infarct dementia of Swedish type and PADMAL (pontine autosomal dominant microangiopathy and leukoencephalopathy) were recently found to be caused by variants of a predicted binding site for miR-29 microRNA located within the $3^{\prime} \mathrm{UTR}$ of COL4A1 gene ${ }^{9,10}$. These diseases differ from other COL4A1related CSVD, and variants found both in Swedish multi-infarct dementia family and PADMAL cases disrupt the same miR-29 binding site leading to upregulation of COL4A1 9 , 10

Despite the variants identified, many CSVD cases remain unexplained genetically even when they appear familial. In this study, we used whole-exome sequencing (WES) to study the genetic background of a cohort of 35 Finnish CSVD patients. We also investigated the 
prevalence of variants in miR-29 binding site of COL4A1 in a cohort of 60 Finnish CSVD patients.

\section{Subjects and Methods}

The study was approved by the Ethical Committee of the Hospital District of Southwest Finland. The approval for the use of patient DNA samples was obtained from the National Supervisory Authority for Welfare and Health (Valvira) and Hospital District of Southwest Finland. Permit for the access to medical records was obtained from the National Institute for Health and Welfare.

\section{Patients}

A cohort of Finnish patients with suspected CADASIL was selected from 365 patients referred for diagnostic testing for NOTCH3 in the Department of Medical Genetics of Turku University Hospital between years 1998-2004. All patients were screened negative for the most common variants affecting function in NOTCH3 (p.Arg133Cys and p.Arg182Cys). Two of the patients were also screened negative for variants in NOTCH3 exons 3-8, 11 and 18-20 and one patient was screened negative for variants in NOTCH3 exons 3, 4 and 8 (NOTCH3 exons numbered consecutively from 1 to 33 according to NM_000435.2). Medical records of the cohort of 365 patients were reviewed to confirm the diagnosis or clinical phenotype. Characteristics of the whole Finnish cohort are summarized in Supplemental Table I. After examining the medical records, 60 patients from the cohort of 365 patients were confirmed to have a diagnosis of VCI and were selected for sequence analysis of the miR-29 microRNA binding site in the 3'UTR of COL4A1 (Figure 1). Of these 60 VCI patients, 35 patients were selected for whole-exome sequencing (Figure 1). The inclusion criteria included the presence of VCI with white matter changes in magnetic resonance imaging, age at onset up to 75 years 
and/or family history of dementia or stroke. Family history was defined from the medical notes and was considered positive if patient had at least one relative suffering from dementia or stroke. The inclusion criteria were used to select the best candidates with adequate clinical information from the cohort of 60 patients to investigate familial forms of VCI.

$\underline{\text { Sanger sequencing of the miR-29 microRNA binding site in the 3'UTR of COL4A1 }}$

The miR-29 microRNA binding site in the 3'UTR of COL4A1 was sequenced in 60 of the samples studied. Sequencing was performed after PCR amplification with Applied Biosystems BigDye terminator version 3.1 sequencing chemistry in an ABI3730xl DNA analyzer (region sequenced: NG_011544.2(NM_001845.5):c.5001_*145). Primers are available upon request. Sequences were analysed using SeqScape Software (Applied Biosystems, Thermo Fisher Scientific, Waltham, MA, USA).

\section{Whole-exome sequencing (WES)}

Details of library preparation and data processing are shown in Supplemental Materials. The stroke-gene panels SGP1 and SGP2 compiled by Ilinca et al. (2019) ${ }^{11}$ was utilized in the variant analysis. Variants located in 168 genes/loci known to be associated with monogenic causes of stroke $\mathrm{i}^{11}$ were extracted from the whole exome data. Mitochondrial genes were excluded from this analysis. Variants were filtered out if they were located in a known genomic duplication region and if they did not pass the VQSR score. Variants included in subsequent analyses had a high or moderate impact annotation score, which excluded synonymous and intronic variants that were not located within splice sites. Variants reported at this stage had an allele frequency $<1 \%$ in gnomAD (v2.1.1) and passed the QC filters described by Patel et al. (2014) ${ }^{12}$. In addition, applying the same QC steps, we searched for rare variants by evaluating all non-synonymous and splice site variants that were absent from 
gnomAD. Additionally, we used the Exomiser software (v11.0.0) to prioritize variants related to CADASIL (ORPHA:136). Exomiser aids finding disease-causing variants from WES data by annotating, filtering and prioritising variants according to user-defined criteria. With Exomiser, autosomal dominant and recessive inheritance models were analyzed to compile a list of the three to four top ranked candidate variants. Only variants that had allele frequency $<1 \%$ in gnomAD were considered in Exomiser analysis. The workflow of the WES data analysis is presented in the Supplemental Figure 1. In silico prediction tools SIFT, PolyPhen2, MutationTaster, LRT, MutationAssessor and CADD were used to predict variant pathogenicity. Only variants with CADD score $\geq 10$ were considered as potentially pathogenic. Variants were classified according to the American College of Medical Genetics and Genomics (ACMG) criteria ${ }^{13}$. Possibly causative variants were submitted to ClinVar (submission ID: SUB7388577, accession numbers SCV001250686, SCV001250687, SCV001250688， SCV001250689， SCV001250690， SCV001250691， SCV001250692, SCV001250693， SCV001250694， SCV001250695， SCV001250696， SCV001250697, SCV001250698, SCV001250699, SCV001250700).

\section{Results}

\section{WES results}

We used WES to identify the variants underlying CSVD in 35 Finnish patients. A positive family history was identified from the patient records for $46 \%(16 / 35)$ of the patients. Of the subjects, $54 \%(19 / 35)$ were women. Clinical characteristics of the patients studied by WES are summarized in Table 1.

Six of the patients (17\%) carried variants possibly affecting function in NOTCH3, HTRA1, COL4A1 or COL4A2, which are genes known to be associated with CSVD (Table 2). 
Additionally, seven of the patients $(20 \%)$ carried variants possibly affecting function in genes associated with other neurological or stroke-related conditions (Table 2). All results of the analyses are presented in Supplemental Tables II-IV. Heterozygous NOTCH3 variants were identified in two patients: c.323G $>$ A, p.(Cys108Tyr) in exon 3 and c.2149C $>$ T, p.(Arg717Cys) in exon 14. Both variants are missense variants resulting either in the gain or loss of a cysteine residue in the EGF-like repeats of NOTCH3 protein that is the most common type of variant causing CADASIL. NOTCH3 variant c.323G $>$ A, p.(Cys108Tyr) has been reported earlier in the literature in a CADASIL patient ${ }^{14}$. The patient carrying the c. $323 \mathrm{G}>\mathrm{A}$ variant had a phenotype consistent with CADASIL and positive family history. The other NOTCH3 variant c. $2149 \mathrm{C}>\mathrm{T}$, p.(Arg717Cys) has not been reported before. It was detected in a VaD patient whose phenotype included multiple strokes, atherosclerosis, cardiomyopathy and heart failure. The patient also had multiple vascular risk factors; diabetes, obesity and smoking.

Furthermore, we identified a heterozygous HTRA1 variant c.961G $>$ A, p.(Ala321Thr), which has been reported in a CARASIL patient compound heterozygous with another HTRA1 variant $^{15}$. Homozygous or compound heterozygous variants affecting function in HTRA1 are known to cause CARASIL, rare autosomal recessive $\mathrm{CSVD}^{6}$, whereas heterozygous HTRA1 variants have been identified in autosomal dominant CSVD which is characterized by delayed onset and absence of extra-neurological features typical for CARASIL ${ }^{7,16}$. The VaD patient carrying the HTRA1 c.961G>A variant had a phenotype consistent with HTRA1CSVD. The age at onset of the patient was 70 years and her phenotype included cerebral microangiopathy, lacunar infarcts, migraine with aura, hypertension and she also suffered from Ménière's disease. Her sibling had a similar phenotype. The patient was not recorded to have extra-neurological features. In addition to the HTRA1 variant, the patient carried the 
COL4A1 variant c.401C $>$ T, p.(Pro134Leu) which was also identified in another patient in our study. We also detected two other collagen variants in two patients, COL4A1 c.2440G $>$ A, p.(Gly814Arg) and COL4A2 c.4291C>T, p.(Arg1431Cys), both occurring on the triple helical domain of the protein. The COL4A1 c.2440G $>$ A, p.(Gly814Arg) variant was identified in a patient who also carried the PSEN2 variant c.53C $>$ T, p.(Thr18Met). The patient had the youngest age of onset in the study cohort (17 years) and his phenotype included vascular leukoencephalopathy, multiple strokes, epilepsy and psychiatric features. Variants affecting function in PSEN2 have been found in patients with early-onset $\mathrm{AD}^{17}$. The COL4A2 variant c.4291C $>$ T, p.(Arg1431Cys) was identified in a CSVD patient whose phenotype included VCI, migraine, mild hearing impairment and balance impairment.

One of the patients carried the APP missense variant c.1795G $>$ A, p.(Glu599Lys), which has previously been reported in patients with Parkinson's disease or dementia with Lewy bodies 18-20. Variants affecting function in $A P P$ are a well-known cause of early-onset $A D$ and cerebral amyloid angiopathy (CAA). Heterozygous variants CCM1 (KRIT1) c.1565T>C, p.(Ile522Thr) and ITM2B c.193C $>$ T, p.(Leu65Phe) were identified in a VaD patient whose phenotype also included behavioural changes and hearing impairment. ITM2B loss-offunction variants resulting lengthened protein products cause autosomal dominant CAA (Familial British and Danish dementia) ${ }^{21,22}$, but ITM2B gene has also been linked to retinal dystrophy ${ }^{23}$. Variants in the KRIT1 (CCM1) and CCM2 genes cause autosomal dominant cerebral cavernous malformations, which are vascular anomalies in the brain ${ }^{24-26}$. We also identified a novel heterozygous $C A C N A 1 A$ variant c. $1348 \mathrm{~T}>\mathrm{C}$, p.(Ser450Pro), CACNA1A is a gene associated with familial hemiplegic migraine, episodic ataxia type 2 and spinocerebellar ataxia type $6^{27}$. The patient carrying the CACNA1A variant c.1348T $>$ C, p.(Ser450Pro) suffered from migraine with aura and her phenotype also included secondary parkinsonism 
and dysphagia. Additionally, we detected a novel heterozygous variant c.115G $>\mathrm{C}$, p.(Asp39His) in the TMEM106B gene. TMEM106B gene is identified as a risk factor for frontotemporal dementia (FTD), but the gene is also linked to hypomyelinating leukodystrophy ${ }^{28,29}$.

Furthermore, we detected variants in C1R and NPPA. These genes are linked to stroke-related conditions. Pathogenic variants in the $C 1 R$ gene are associated with autosomal dominant periodontal Ehlers-Danlos syndrome ${ }^{30}$, which is a syndrome that may include vascular anomalies $^{31}$. However, the heterozygous $C 1 R$ variant c.336G $>C$, p.(Met112Ile) detected in our study is present in $0.2 \%$ of the Finnish population according to the gnomAD database and the clinical significance of the variant is interpreted both as uncertain and likely benign in ClinVar database. The patient carrying the $C 1 R$ variant c.336G $>C$, p.(Met112Ile) also carried the CCM2 variant c.1346T $>$ G, p.(Ile449Ser) and her phenotype included walking and balance impairment, hypercholesterolemia, diabetes, myocardial infarction and coronary artery disease, and she had family history positive for strokes. The NPPA gene is linked to familial atrial fibrillation $^{32,33}$, which may cause cardioembolic stroke. In our study, the heterozygous NPPA variant c.377G $>$ A, p.(Arg126Gln) was identified in a patient who suffered from angina pectoris.

Sanger sequencing of the miR-29 microRNA binding site in 3'UTR of COL4A1

A total of 60 Finnish CSVD patients were screened for variants in the miR-29 microRNA binding site in 3'UTR of COL4A1. Sanger sequencing did not reveal any variants in the miR29 microRNA binding site in 3'UTR of COL4A1. 


\section{Discussion}

Although VCI is very commonly found in subjects with dementia, research of the disease lags behind other dementing conditions. There are no common standards in the studies of VCI or universally accepted diagnostic criteria for the disease, which complicates reproducibility of research in this area. Research of VCI has also lacked large, wellcharacterized patient cohorts. Even though monogenic forms of VCI are considered rare, the identification and characterizations of these forms of disease may considerably contribute to the understanding of the molecular pathogenesis of dementing diseases. With this in mind, we investigated the genetics of VCI by studying a homogenous Finnish cohort with welldefined clinical features, ascertained by the individual revision of medical records. Our study resulted in the detection of several variants possibly affecting function both in known CSVD genes and in genes linked to other neurological disorders or stroke-related conditions.

Six patients carried variants possibly affecting function in the known CSVD genes: NOTCH3, COL4A1, COL4A2 and HTRA1, accounting for as high as $17 \%$ of all the patients. The relatively high proportion of these variants probably reflects the original selection of patients for CADASIL (NOTCH3) testing, and our selection criteria for exome sequencing might have further favored a CSVD type phenotype. Even so, these results support pathogenic roles of variants in COL4A1, COL4A2 and HTRA1 in CSVD and VCI. This is in line with the recent study by Ilinca et al, where variants in NOTCH3, COL4A1 and COL4A2 were found in a WES study in patients with suspected monogenic form of stroke $\mathrm{e}^{34}$.

Interestingly, we also detected several variants in genes associated with other dementing or neurodegenerative disorders, which may indicate the overlapping pathologies between these disorders. Detection of variants in the AD-linked genes APP and PSEN2 may represent a 
genetic connection of CSVD with AD pathology. Several studies have shown a relationship between $\mathrm{CSVD}$ and $\mathrm{AD}{ }^{35}$. $\mathrm{AD}$ very often occurs concomitantly with vascular or other neurodegenerative pathology ${ }^{36}$, but it is still unknown how pathologies of AD and CSVD interact with each other ${ }^{37}$. One of the study subjects carried variants both in CSVD-linked gene COL4A1 and AD-linked gene PSEN2, so it is possible that both variants had a role in his disease, which started at an exceptionally early age (17 years). In this study, three patients carried more than one variant that possibly affect function and may have roles in patients' disease, indicating possible oligogenic cause of VCI. In addition to AD-linked genes, we observed variants possibly affecting function in genes linked to FTD and migraine. Although there are not many studies on the relationship between vascular impairment and FTD, an effect of vascular lesions in the pathogenesis of FTD has been suggested ${ }^{38}$. It is also possible that phenotypic similarities may have been the cause for detection of variants in genes linked to FTD and migraine in our study.

Distinguishing VCI from other forms of dementia and neurodegenerative diseases may be challenging, highlighting the importance of the evaluation of the clinical phenotype of the study subjects when studying a particular disease entity. In our study, the clinical information of the patients was obtained from the medical records, but the amount of the available information varied between patients. A large proportion of the subjects were later diagnosed with another disease than VCI, although CADASIL testing was originally performed (Supplemental Table I). Furthermore, less than half (46\%) of the patients showed a positive family history, the rest of the subjects possibly representing sporadic cases. Samples from the relatives of the patients were not available and therefore we could not analyse the segregation of the detected variants. In addition, the cohort did not include any cases confirmed by 
neuropathological examination, which could have facilitated the diagnosing and characterization of patients.

Previous studies have shown that PADMAL and multi-infarct dementia of Swedish type are caused by variants in an untranslated region of $C O L 4 A 1^{9,10}$, but there is limited knowledge on the prevalence of these variants among CSVD patients in different populations. Here we screened the miR-29 microRNA binding site in 3'UTR of COL4A1 in 60 CSVD patients of Finnish origin, but found no variants to be present in our cohort. The small sample size and possible clinical heterogeneity of the cohort included in this analysis can be possible reasons for the negative results obtained. Despite these, this analysis suggests that COL4A1 3'UTR variants are a very rare cause of CSVD and they may be restricted to certain populations and/or clinical phenotypes. Further studies including larger sample sizes from different ethnicities are needed to fully reveal the role of COL4A1 3'UTR variants in the whole spectrum of CSVD.

Patients that remained negative may represent disorders that are inherited in a polygenic rather than a Mendelian manner. Two patients carried variants in genes associated with atrial fibrillation or Ehlers-Danlos syndrome, which are distinct from other variants detected in genes linked to CSVD or other neurological disorders, but which could also have roles in the vascular phenotypes of the patients. Vascular risk factors, such as hypertension and type 2 diabetes, and environmental risk factors, such as smoking and alcohol consumption, have also a role in the pathogenesis of $\mathrm{VCI}^{39}$. Some of the patients may carry pathogenic intronic variants, copy number variants, repeat expansions, structural variants or methylation changes that were not possible to detect with WES. In addition, some of the patients may carry 
variants in novel genes that have not yet been found to be associated with VCI or other forms of neurodegeneration.

It should also be noted, that the stroke-gene panel used in the variant analysis needs to be updated in future studies, as more data on the genetic backgound of cerebrovascular phenotypes will accumulate. Pathogenicity of the identified variants with uncertain significance should be confirmed with functional studies and larger data sets.

These data provide evidence for improved information and guidance in genetic testing of familial VCI. Although there are no curative treatments available for VCI, identifying disease causing variants may aid making a precise diagnosis and provide information on the prognosis. Genetic diagnosis provides the opportunity for diagnostic testing of other affected family members and predictive screening of the unaffected relatives.

In conclusion, our results support pathogenic roles of variants in COL4A1, COL4A2, and HTRA1 in CSVD and VCI. The variants identified in genes linked with neurodegenerative diseases suggest that vascular pathogenic mechanisms are linked to neurodegenerative conditions. Although more research needs to be done to reveal how these variants cause disease, our study provides novel insights into the molecular basis of VCI.

\section{Acknowledgements}

We thank Prof. (emeritus) Hannu Kalimo and the CADASIL group for discussions when planning this study.

\section{Funding}


This study was supported by Academy of Finland (294817), Helsinki University Hospital Competetive Fund, and The Finnish Medical Society Duodecim.

\section{Conflict of Interest}

The authors declare no conflict of interest. 


\section{References}

1. Dichgans M, Leys D. Vascular Cognitive Impairment. Circ.Res. 2017; 120: 573-591.

2. O'Brien JT, Thomas A. Vascular dementia. Lancet. 2015; 386: 1698-1706.

3. Pasi M, Cordonnier C. Clinical Relevance of Cerebral Small Vessel Diseases. Stroke. 2020; 51: 47-53.

4. Marini S, Anderson CD, Rosand J. Genetics of Cerebral Small Vessel Disease. Stroke. 2020; 51: 12-20.

5. Joutel A, Corpechot C, Ducros A, Vahedi K, Chabriat H, Mouton P, et al. Notch3 mutations in CADASIL, a hereditary adult-onset condition causing stroke and dementia. Nature. 1996; 383: 707-710.

6. Hara K, Shiga A, Fukutake T, Nozaki H, Miyashita A, Yokoseki A, et al. Association of HTRA1 mutations and familial ischemic cerebral small-vessel disease. N.Engl.J.Med. 2009; 360: 1729-1739.

7. Verdura E, Herve D, Scharrer E, Amador Mdel M, Guyant-Marechal L, Philippi A, et al. Heterozygous HTRA1 mutations are associated with autosomal dominant cerebral small vessel disease. Brain. 2015; 138: 2347-2358.

8. Labelle-Dumais C, Kuo DS, Gould DB. COL4A1 and COL4A2 mutations and disease: insights into pathogenic mechanisms and potential therapeutic targets. hmg. 2012; 21: R97R110. 
9. Siitonen M, Borjesson-Hanson A, Poyhonen M, Ora A, Pasanen P, Bras J, et al. Multiinfarct dementia of Swedish type is caused by a 3'UTR mutation of COL4A1. Brain. 2017; 140: e29.

10. Verdura E, Herve D, Bergametti F, Jacquet C, Morvan T, Prieto-Morin C, et al. Disruption of a miR-29 binding site leading to COL4A1 upregulation causes pontine autosomal dominant microangiopathy with leukoencephalopathy. Ann.Neurol. 2016; 80: 741753.

11. Ilinca A, Samuelsson S, Piccinelli P, Soller M, Kristoffersson U, Lindgren AG. A stroke gene panel for whole-exome sequencing. Eur.J.Hum.Genet. 2019; 27: 317-324.

12. Patel ZH, Kottyan LC, Lazaro S, Williams MS, Ledbetter DH, Tromp H, et al. The struggle to find reliable results in exome sequencing data: filtering out Mendelian errors. Front.Genet. 2014; 5: 16.

13. Richards S, Aziz N, Bale S, Bick D, Das S, Gastier-Foster J, et al. Standards and guidelines for the interpretation of sequence variants: a joint consensus recommendation of the American College of Medical Genetics and Genomics and the Association for Molecular Pathology. Genet.Med. 2015; 17: 405-424.

14. Opherk C, Herzog J, Dichgans M, Peters N, Luedtke R. Long-term prognosis and causes of death in CADASIL: a retrospective study in 411 patients. Brain. 2004; 127: 2533-2539.

15. Bianchi S, Di Palma C, Gallus GN, Taglia I, Poggiani A, Rosini F, et al. Two novel HTRA1 mutations in a European CARASIL patient. Neurology. 2014; 82: 898-900. 
16. Nozaki H, Kato T, Nihonmatsu M, Saito Y, Mizuta I, Noda T, et al. Distinct molecular mechanisms of HTRA1 mutants in manifesting heterozygotes with CARASIL. Neurology. 2016; 86: 1964-1974.

17. Guerreiro RJ, Gustafson DR, Hardy J. The genetic architecture of Alzheimer's disease: beyond APP, PSENs and APOE. Neurobiol.Aging. 2012; 33: 437-456.

18. Ghani M, Lang AE, Zinman L, Nacmias B, Sorbi S, Bessi V, et al. Mutation analysis of patients with neurodegenerative disorders using NeuroX array. Neurobiol.Aging. 2015; 36: 545.e9-545.14.

19. Schulte EC, Fukumori A, Mollenhauer B, Hor H, Arzberger T, Perneczky R, et al. Rare variants in beta-Amyloid precursor protein (APP) and Parkinson's disease. Eur.J.Hum.Genet. 2015; 23: 1328-1333.

20. Geiger JT, Ding J, Crain B, Pletnikova O, Letson C, Dawson TM, et al. Next-generation sequencing reveals substantial genetic contribution to dementia with Lewy bodies.

Neurobiol.Dis. 2016; 94: 55-62.

21. Vidal R, Frangione B, Rostagno A, Mead S, Revesz T, Plant G, et al. A stop-codon mutation in the BRI gene associated with familial British dementia. Nature. 1999; 399: 776781.

22. Vidal R, Révész T, Rostagno A, Kim E, Holton JL, Bek T, et al. A decamer duplication in the $3^{\prime}$ region of the $B R I$ gene originates an amyloid peptide that is associated with dementia in a Danish kindred. Proc.Natl.Acad.Sci.USA. 2000; 97: 4920-4925.

23. Audo I, Bujakowska K, Orhan E, El Shamieh S, Sennlaub F, Guillonneau X, et al. The familial dementia gene revisited: a missense mutation revealed by whole-exome sequencing 
identifies ITM2B as a candidate gene underlying a novel autosomal dominant retinal dystrophy in a large family. Hum.Mol.Genet. 2014; 23: 491-501.

24. Notelet L, Chapon F, Khoury S, Vahedi K, Chodkiewicz JP, Courtheoux P, et al. Familial cavernous malformations in a large French kindred: mapping of the gene to the CCM1 locus on chromosome 7q. J.Neurol.Neurosurg.Psychiatry. 1997; 63: 40-45.

25. Craig HD, Gunel M, Cepeda O, Johnson EW, Ptacek L, Steinberg GK, et al. Multilocus linkage identifies two new loci for a mendelian form of stroke, cerebral cavernous malformation, at 7p15-13 and 3q25.2-27. Hum.Mol.Genet. 1998; 7: 1851-1858.

26. Liquori CL, Berg MJ, Siegel AM, Huang E, Zawistowski JS, Stoffer T, et al. Mutations in a gene encoding a novel protein containing a phosphotyrosine-binding domain cause type 2 cerebral cavernous malformations. Am.J.Hum.Genet. 2003; 73: 1459-1464.

27. Rajakulendran S, Kaski D, Hanna MG. Neuronal P/Q-type calcium channel dysfunction in inherited disorders of the CNS. Nat.Rev.Neurol. 2012; 8: 86-96.

28. Van Deerlin VM, Sleiman PM, Martinez-Lage M, Chen-Plotkin A, Wang LS, GraffRadford NR, et al. Common variants at 7p21 are associated with frontotemporal lobar degeneration with TDP-43 inclusions. Nat.Genet. 2010; 42: 234-239.

29. Simons C, Dyment D, Bent SJ, Crawford J, D'Hooghe M, Kohlschutter A, et al. A recurrent de novo mutation in TMEM106B causes hypomyelinating leukodystrophy. Brain. 2017; 140: 3105-3111.

30. Kapferer-Seebacher I, Pepin M, Werner R, Aitman TJ, Nordgren A, Stoiber H, et al. Periodontal Ehlers-Danlos Syndrome Is Caused by Mutations in C1R and C1S, which 
Encode Subcomponents C1r and C1s of Complement. Am.J.Hum.Genet. 2016; 99: 10051014.

31. Cikla U, Sadighi A, Bauer A, Baskaya MK. Fatal Ruptured Blood Blister-like Aneurysm of Middle Cerebral Artery Associated with Ehlers-Danlos Syndrome Type VIII (Periodontitis Type). J.Neurol.Surg.Rep. 2014; 75: 210.

32. Hodgson-Zingman DM, Karst ML, Zingman LV, Heublein DM, Darbar D, Herron KJ, et al. Atrial natriuretic peptide frameshift mutation in familial atrial fibrillation. N.Engl.J.Med. 2008; 359: 158-165.

33. Abraham RL, Yang T, Blair M, Roden DM, Darbar D. Augmented potassium current is a shared phenotype for two genetic defects associated with familial atrial fibrillation. J.Mol.Cell.Cardiol. 2010; 48: 181-190.

34. Ilinca A, Martinez-Majander N, Samuelsson S, Piccinelli P, Truve K, Cole J, et al. Whole-Exome Sequencing in 22 Young Ischemic Stroke Patients With Familial Clustering of Stroke. Stroke. 2020; 51: 1056-1063.

35. Cai Z, Wang C, He W, Tu H, Tang Z, Xiao M, et al. Cerebral small vessel disease and Alzheimer's disease. Clin.Interv.Aging. 2015; 10: 1695-1704.

36. Boyle PA, Yu L, Wilson RS, Leurgans SE, Schneider JA, Bennett DA. Person-specific contribution of neuropathologies to cognitive loss in old age. Ann.Neurol. 2018; 83: 74-83.

37. Liu Y, Braidy N, Poljak A, Chan DKY, Sachdev P. Cerebral small vessel disease and the risk of Alzheimer's disease: A systematic review. Ageing Research Reviews. 2018; 47: 4148. 
38. Thal DR, von Arnim CA, Griffin WS, Mrak RE, Walker L, Attems J, et al.

Frontotemporal lobar degeneration FTLD-tau: preclinical lesions, vascular, and Alzheimerrelated co-pathologies. J.Neural Transm.(Vienna). 2015; 122: 1007-1018.

39. Dichgans M, Zietemann V. Prevention of vascular cognitive impairment. Stroke. 2012; 43: $3137-3146$.

40. Rogaev EI, Sherrington R, Rogaeva EA, Levesque G, Ikeda M, Liang Y, et al. Familial Alzheimer's disease in kindreds with missense mutations in a gene on chromosome 1 related to the Alzheimer's disease type 3 gene. Nature. 1995; 376: 775-778.

41. Rentzsch P, Witten D, Cooper GM, Shendure J, Kircher M. CADD: predicting the deleteriousness of variants throughout the human genome. Nucleic Acids Res. 2019; 47: D886-D894. 


\section{Figure legends:}

Figure 1. Schematic presentation of the study describing the workflow of selection of patients and genetic examinations. AAO, age-at-onset; MRI, magnetic resonance imaging; VCI, vascular cognitive impairment; WES, whole-exome sequencing. 
Tables:

Table 1. Characteristics of the 35 patients selected for WES.

\begin{tabular}{|c|c|c|c|c|c|c|c|c|c|}
\hline Sample & Gender & $\begin{array}{l}\text { AA } \\
\text { O }\end{array}$ & \begin{tabular}{|l|}
$\begin{array}{l}\text { Diagnosis/clinical } \\
\text { features }\end{array}$ \\
\end{tabular} & \begin{tabular}{|l|} 
Family \\
history
\end{tabular} & $\begin{array}{l}\text { Affected family } \\
\text { members }\end{array}$ & \begin{tabular}{|l|} 
Migrain \\
e
\end{tabular} & \begin{tabular}{|l|} 
Hypertensio \\
n
\end{tabular} & Other risk factors & \begin{tabular}{|l|}
$\begin{array}{l}\text { Other } \\
\text { conditions }\end{array}$ \\
\end{tabular} \\
\hline 9 & $\mathrm{~F}$ & 74 & $\mathrm{VaD}$ & Yes & $\begin{array}{l}\text { Father, eight } \\
\text { siblings } \\
\text { (dementia and } \\
\text { multiple } \\
\text { cerebral } \\
\text { strokes) } \\
\end{array}$ & No & Yes & Diabetes & \\
\hline 43 & $\mathrm{M}$ & 64 & VaD/dementia NAS & $\mathrm{n} / \mathrm{a}$ & & No & Yes & & \\
\hline 48 & M & 55 & $\begin{array}{l}\text { VaD, depression, } \\
\text { psychosis }\end{array}$ & Yes & $\begin{array}{l}\text { Sibling with } \\
\text { same clinical } \\
\text { features). Also } \\
\text { uncle with } \\
\text { moton neuron } \\
\text { disease }\end{array}$ & No & No & & \\
\hline 57 & $\mathrm{~F}$ & 61 & $\begin{array}{l}\text { VaD, schizoaffective } \\
\text { psychosis }\end{array}$ & No & & No & No & $\begin{array}{l}\text { Obesity, myocardial } \\
\text { infarction }\end{array}$ & \\
\hline 102 & $\mathrm{M}$ & 57 & $\mathrm{VaD}$ & $\mathrm{n} / \mathrm{a}$ & & No & Yes & & \\
\hline 108 & $\mathrm{M}$ & 58 & $\mathrm{VaD}$ & Yes & $\begin{array}{l}\begin{array}{l}\text { Father } \\
\text { (dementia, } \\
\text { AAO 60 years) }\end{array} \\
\end{array}$ & No & No & & \\
\hline 110 & $M$ & 58 & $\mathrm{VaD}$ & $\mathrm{n} / \mathrm{a}$ & & No & Yes & & \\
\hline 125 & $\mathrm{~F}$ & 65 & $\mathrm{VaD}$ & Yes & $\begin{array}{l}\text { Uncle } \\
\text { (dementia, } \\
\text { before age 60), } \\
\text { sibling (died of } \\
\text { cerebral }\end{array}$ & Yes & Yes & Hypercholesterolemia & \\
\hline
\end{tabular}




\begin{tabular}{|c|c|c|c|c|c|c|c|c|c|}
\hline & & & & & $\begin{array}{l}\text { hemorrage at } \\
\text { age } 59 \text { years) }\end{array}$ & & & & \\
\hline 137 & $\mathrm{~F}$ & 65 & $\begin{array}{l}\text { VaD, parkinsonismus } \\
\text { secundaris }\end{array}$ & No & & Yes & Yes & $\begin{array}{l}\text { Coronary artery } \\
\text { disease }\end{array}$ & \\
\hline 140 & $\mathrm{~F}$ & 43 & $\mathrm{VaD}$ & Yes & $\begin{array}{l}\text { Father (died of } \\
\text { stroke at age } \\
57 \text { ), several } \\
\text { siblings } \\
\text { (strokes), one } \\
\text { sibling } \\
\text { (epilepsy) }\end{array}$ & No & Yes & $\begin{array}{l}\text { Hypercholesterolemia } \\
\text {, diabetes, myocardial } \\
\text { infarction, coronary } \\
\text { artery disease }\end{array}$ & \\
\hline 147 & $\mathrm{~F}$ & 74 & $\mathrm{VaD}$ & Yes & \begin{tabular}{|l|} 
Sibling \\
(progressive \\
dementing \\
disorder, AAO \\
60 years) \\
\end{tabular} & No & Yes & $\begin{array}{l}\text { Coronary artery } \\
\text { disease }\end{array}$ & \\
\hline 156 & $\mathrm{M}$ & 17 & $\begin{array}{l}\text { VaD, epilepsy, } \\
\text { psychiatric features }\end{array}$ & $\mathrm{n} / \mathrm{a}$ & & Yes & No & & \\
\hline 160 & $\mathrm{~F}$ & 56 & VCI & $\mathrm{n} / \mathrm{a}$ & & Yes & Yes & Hypercholesterolemia & \\
\hline 161 & $\mathrm{M}$ & 65 & $\mathrm{VaD}$ & $\mathrm{n} / \mathrm{a}$ & & No & No & & \\
\hline 184 & $\mathrm{~F}$ & 71 & $\mathrm{VaD}$ & $\mathrm{n} / \mathrm{a}$ & & No & Yes & Angina pectoris & \\
\hline 185 & $\mathrm{~F}$ & 62 & $\mathrm{VaD}$ & Yes & $\begin{array}{l}\text { Father (stroke), } \\
\text { mother } \\
\text { (cognitive } \\
\text { impairment). } \\
\text { Also child and } \\
\text { several relatives } \\
\text { suffering from } \\
\text { hearing loss. }\end{array}$ & No & Yes & & \\
\hline 204 & $\mathrm{M}$ & 69 & $\mathrm{VaD}$ & $\mathrm{n} / \mathrm{a}$ & & No & No & Myocardial infarction & \\
\hline 207 & $\mathrm{~F}$ & 74 & $\mathrm{VaD}$ & Yes & Father (cerebral & Yes & Yes & Hypercholesterolemia & \\
\hline
\end{tabular}




\begin{tabular}{|c|c|c|c|c|c|c|c|c|c|}
\hline & & & & & $\begin{array}{l}\text { hemorrage), } \\
\text { sibling (aphasia } \\
\text { and hemiplegia, } \\
\text { AAO } 66 \text { years) }\end{array}$ & & & & \\
\hline 233 & $\mathrm{~F}$ & 73 & $\mathrm{VaD}$ & Yes & $\begin{array}{l}\text { Mother, } \\
\text { identical twin } \\
\text { (dementia, } \\
\text { before age } 70 \text { ) }\end{array}$ & No & Yes & $\begin{array}{l}\text { Diabetes, coronary } \\
\text { artery disease }\end{array}$ & \\
\hline 235 & M & 56 & $\mathrm{VaD}$ & $\mathrm{n} / \mathrm{a}$ & & No & Yes & $\begin{array}{l}\text { Atherosclerosis, } \\
\text { cardiomyopathy, } \\
\text { heart failure, diabetes, } \\
\text { obesity, smoking }\end{array}$ & \\
\hline 236 & $\mathrm{M}$ & 64 & $\mathrm{VaD}$ & $\mathrm{n} / \mathrm{a}$ & & No & Yes & $\begin{array}{l}\text { Diabetes, } \\
\text { hypercholesterolemia }\end{array}$ & \\
\hline 255 & $\mathrm{~F}$ & 31 & $\mathrm{VaD}$ & Yes & $\begin{array}{l}\text { Grandmother } \\
\text { (hemiplegia, } \\
\text { several strokes, } \\
\text { dementia) }\end{array}$ & Yes & No & Smoking & $\begin{array}{l}\text { Chronic } \\
\text { obstructive } \\
\text { pulmonary } \\
\text { disease } \\
\end{array}$ \\
\hline 260 & $\mathrm{~F}$ & 68 & $\mathrm{VaD}$ & $\mathrm{n} / \mathrm{a}$ & & No & Yes & Hypercholesterolemia & \\
\hline 266 & $\mathrm{~F}$ & 61 & VaD, depression & Yes & $\begin{array}{l}\text { Sibling } \\
\text { (dementia, } \\
\text { before age 50) }\end{array}$ & No & No & & \\
\hline 269 & $\mathrm{M}$ & 54 & $\mathrm{VaD}$ & No & & Yes & No & $\begin{array}{l}\text { Heart failure, atrial } \\
\text { fibrillation, previous } \\
\text { heavy alcohol } \\
\text { consumption } \\
\end{array}$ & $\begin{array}{l}\text { Colitis } \\
\text { ulcerosa }\end{array}$ \\
\hline 273 & M & 61 & VCI & Yes & $\begin{array}{l}\begin{array}{l}\text { Mother } \\
\text { (multiple }\end{array} \\
\text { strokes, first at } \\
\text { age 42), sibling } \\
\text { (stroke at age } \\
\text { 50), sibling }\end{array}$ & No & No & Hypercholesterolemia & \\
\hline
\end{tabular}




\begin{tabular}{|c|c|c|c|c|c|c|c|c|c|}
\hline & & & & & $\begin{array}{l}\text { (multiple } \\
\text { strokes, first at } \\
\text { age 55), two } \\
\text { aunts (stroke at } \\
\text { young age), } \\
\text { uncle (stroke at } \\
\text { young age) }\end{array}$ & & & & \\
\hline 283 & $\mathrm{~F}$ & 60 & $\mathrm{VaD}$ & Yes & $\begin{array}{l}\text { Father (multiple } \\
\text { strokes, first at } \\
\text { age 46), } \\
\text { maternal aunt } \\
\text { (stroke, } \\
\text { migraine and } \\
\text { dementia). } \\
\text { Several } \\
\text { relatives } \\
\text { suffering from } \\
\text { cardiovascular } \\
\text { disease and } \\
\text { migraine }\end{array}$ & No & Yes & Hypercholesterolemia & \\
\hline 289 & $\mathrm{M}$ & 48 & $\mathrm{VaD}$ & $\mathrm{n} / \mathrm{a}$ & & No & Yes & $\begin{array}{l}\text { Heart arrhythmia, } \\
\text { smoking }\end{array}$ & \\
\hline 290 & $\mathrm{~F}$ & 56 & $\mathrm{VaD}$ & $\mathrm{n} / \mathrm{a}$ & & No & No & Hypercholesterolemia & \\
\hline 293 & $\mathrm{M}$ & 56 & $\mathrm{VaD}$ & $\mathrm{n} / \mathrm{a}$ & & Yes & Yes & & \\
\hline 343 & $\mathrm{M}$ & 68 & $\mathrm{VaD}$ & No & & No & No & Hypercholesterolemia & \\
\hline 379 & $\mathrm{~F}$ & 70 & $\mathrm{VaD}$ & Yes & $\begin{array}{l}\text { Sibling with } \\
\text { same clinical } \\
\text { features } \\
\text { (dementia, } \\
\text { hearing loss). } \\
\text { Child suffering } \\
\text { from migraine. }\end{array}$ & Yes & Yes & Hypercholesterolemia & $\begin{array}{l}\text { Ménière's } \\
\text { disease }\end{array}$ \\
\hline
\end{tabular}




\begin{tabular}{|c|c|c|c|c|c|c|c|c|}
\hline 380 & $\mathrm{~F}$ & 60 & VaD, epilepsy & Yes & \begin{tabular}{|l} 
Mother \\
(multiple \\
strokes)
\end{tabular} & No & Yes & Obesity \\
\hline 383 & $\mathrm{M}$ & 68 & $\mathrm{VaD}$ & Yes & $\begin{array}{l}\text { Mother and } \\
\text { sibling (strokes } \\
\text { before age } 70 \text { ) }\end{array}$ & No & Yes & $\begin{array}{l}\text { Coronary artery } \\
\text { disease, } \\
\text { hypercholesterolemia }\end{array}$ \\
\hline 387 & $\mathrm{~F}$ & 73 & VaD & $n / a$ & & No & Yes & Smoking \\
\hline
\end{tabular}

AAO, age at onset; F, female; M, male; NAS, Non Aliter Specificatus (Not Further Specified); n/a, no information available; VaD, vascular dementia; VCI, vascular cognitive impairment. 
Table 2. Possibly causative variants identified by WES.

\begin{tabular}{|c|c|c|c|c|c|c|c|c|c|c|c|c|c|c|c|c|c|c|c|c|}
\hline $\begin{array}{l}\text { Pa } \\
\text { tie } \\
\text { nt }\end{array}$ & $\begin{array}{l}\text { A } \\
\text { A } \\
\mathbf{O}\end{array}$ & $\begin{array}{l}\text { Fa } \\
\text { mi } \\
\text { ly } \\
\text { his } \\
\text { to } \\
\text { ry }\end{array}$ & Gene & $\begin{array}{l}\text { Nuc } \\
\text { leoti } \\
\text { de } \\
\text { cha } \\
\text { nge }\end{array}$ & $\begin{array}{l}\text { Amin } \\
\text { o acid } \\
\text { chang } \\
\text { e }\end{array}$ & $\begin{array}{l}\text { Zy } \\
\text { goc } \\
\text { ity }\end{array}$ & $\begin{array}{l}\text { Refere } \\
\text { nce } \\
\text { sequen } \\
\text { ce }\end{array}$ & $\begin{array}{l}\text { dbSN } \\
\text { P ID }\end{array}$ & $\begin{array}{l}\text { Allel } \\
\text { e } \\
\text { freq } \\
\text { uenc } \\
\text { y } \\
\text { (gno } \\
\text { mA } \\
\text { D } \\
\text { total } \\
\text { ) }\end{array}$ & \begin{tabular}{|l} 
Allel \\
e \\
freq \\
uenc \\
y \\
(gno \\
mA \\
D \\
Finn \\
ish)
\end{tabular} & $\begin{array}{l}\text { C } \\
\text { A } \\
\text { D } \\
\text { D } \\
\text { ph } \\
\text { re } \\
\text { d }\end{array}$ & $\begin{array}{l}\text { Poly } \\
\text { Phe } \\
\text { n2 }\end{array}$ & $\begin{array}{l}\text { Mutat } \\
\text { ionTa } \\
\text { ster }\end{array}$ & $\begin{array}{l}\mathbf{S I} \\
\mathbf{F} \\
\mathbf{T}\end{array}$ & $\begin{array}{l}\text { AC } \\
\text { MG } \\
\text { classi } \\
\text { ficati } \\
\text { on }\end{array}$ & $\begin{array}{l}\text { Condition associated with } \\
\text { the gene }\end{array}$ & \begin{tabular}{|l} 
Con \\
ditio \\
n \\
assoc \\
iated \\
with \\
the \\
varia \\
nt, \\
refer \\
ence
\end{tabular} & $\begin{array}{l}\text { Det } \\
\text { ect } \\
\text { ed } \\
\text { in } \\
\text { str } \\
\text { oke } \\
- \\
\text { pa } \\
\text { nel } \\
\text { ana } \\
\text { lysi } \\
\text { s }\end{array}$ & $\begin{array}{l}\text { Det } \\
\text { ecte } \\
\text { d in } \\
\text { Exo } \\
\text { mis } \\
\text { er } \\
\text { ana } \\
\text { lysi } \\
\text { s }\end{array}$ & $\begin{array}{l}\text { Det } \\
\text { ect } \\
\text { ed } \\
\text { in } \\
\text { rar } \\
\text { e } \\
\text { var } \\
\text { ian } \\
\text { t } \\
\text { ana } \\
\text { lysi } \\
\text { s }\end{array}$ \\
\hline $\begin{array}{r}10 \\
2\end{array}$ & $\begin{array}{l}5 \\
7\end{array}$ & $\mathrm{n} / \mathrm{a}$ & \begin{tabular}{|l|}
$C C M$ \\
1 \\
$(K R I T$ \\
$1)$
\end{tabular} & $\begin{array}{l}\mathrm{c} .15 \\
65 \mathrm{~T} \\
>\mathrm{C}\end{array}$ & $\begin{array}{l}\text { p.(Ile5 } \\
\text { 22Thr } \\
\text { ) }\end{array}$ & Het & $\begin{array}{l}\text { NM } 19 \\
445 \overline{6} .1\end{array}$ & $\begin{array}{l}\text { rs } 758 \\
1889 \\
72\end{array}$ & $\begin{array}{l}0.00 \\
0007 \\
118\end{array}$ & $\begin{array}{l}0.00 \\
0015 \\
58\end{array}$ & $\begin{array}{l}22 \\
, 2\end{array}$ & $\mathrm{P}$ & D & $\mathrm{T}$ & 3 & $\begin{array}{l}\text { Cerebral cavernous } \\
\text { malformations } 24,25\end{array}$ & $\begin{array}{l}\text { Nove } \\
1\end{array}$ & Yes & No & No \\
\hline $\begin{array}{r}10 \\
2\end{array}$ & & & $\begin{array}{l}\text { ITM2 } \\
B\end{array}$ & $\begin{array}{l}\text { c. } 19 \\
3 \mathrm{C}> \\
\mathrm{T}\end{array}$ & $\begin{array}{l}\text { p.(Leu } \\
65 \text { Phe } \\
\text { ) }\end{array}$ & Het & $\begin{array}{l}\text { NM_02 } \\
1999.4\end{array}$ & & 0 & 0 & 32 & D & D & D & 3 & $\begin{array}{l}\text { Cerebral amyloid angiopathy, } \\
\text { retinal dystrophy } 21-23\end{array}$ & $\begin{array}{l}\text { Nove } \\
1\end{array}$ & Yes & Yes & Yes \\
\hline $\begin{array}{r}13 \\
7\end{array}$ & $\begin{array}{l}6 \\
5\end{array}$ & No & $\begin{array}{l}\text { CACN } \\
\text { A1A }\end{array}$ & $\begin{array}{l}\text { c. } 13 \\
48 \mathrm{~T} \\
>\mathrm{C}\end{array}$ & $\begin{array}{l}\text { p.(Ser } \\
450 \mathrm{Pr} \\
\text { o) }\end{array}$ & Het & $\begin{array}{l}\text { NM } 00 \\
112722 \\
2.1\end{array}$ & \begin{tabular}{|l|} 
rs 130 \\
8599 \\
413 \\
\end{tabular} & $\begin{array}{l}0.00 \\
0007\end{array}$ & $\begin{array}{l}0.00 \\
008\end{array}$ & $\begin{array}{l}26 \\
4\end{array}$ & $\mathrm{P}$ & D & D & 3 & $\begin{array}{l}\text { Episodic ataxia, familial } \\
\text { hemiplegic migraine, } \\
\text { spinocerebellar ataxia }^{27}\end{array}$ & $\begin{array}{l}\text { Nove } \\
1\end{array}$ & Yes & Yes & No \\
\hline $\begin{array}{r}14 \\
0 \\
\end{array}$ & $\begin{array}{l}4 \\
3\end{array}$ & $\begin{array}{l}\mathrm{Ye} \\
\mathrm{s}\end{array}$ & C1R & $\begin{array}{l}\text { c. } 33 \\
6 \mathrm{G}> \\
\mathrm{C}\end{array}$ & $\begin{array}{l}\text { p.(Met } \\
112 \text { Ile } \\
\text { ) }\end{array}$ & Het & $\begin{array}{l}\text { NM } 00 \\
173 \overline{3} .7\end{array}$ & $\begin{array}{l}\text { rs139 } \\
5314 \\
04 \\
\end{array}$ & $\begin{array}{l}0.00 \\
2823\end{array}$ & $\begin{array}{l}0.00 \\
2157\end{array}$ & $\begin{array}{l}22 \\
, 2\end{array}$ & D & D & D & 3 & $\begin{array}{l}\text { Ehlers-Danlos syndrome, } \\
\text { periodontal type } 1^{30}\end{array}$ & $\begin{array}{l}\text { Nove } \\
1\end{array}$ & Yes & No & No \\
\hline $\begin{array}{r}14 \\
0\end{array}$ & & & $\begin{array}{l}C C M \\
2\end{array}$ & $\begin{array}{l}\mathrm{c} .13 \\
46 \mathrm{~T} \\
>\mathrm{G}\end{array}$ & $\begin{array}{l}\text { p.(Ile4 } \\
\text { 49Ser) }\end{array}$ & Het & $\begin{array}{l}\text { NM } 00 \\
102983 \\
5.2\end{array}$ & & 0 & 0 & 22 & D & D & D & 3 & $\begin{array}{l}\text { Cerebral cavernous } \\
\text { malformations } 25,26\end{array}$ & $\begin{array}{l}\text { Nove } \\
1\end{array}$ & Yes & Yes & Yes \\
\hline $\begin{array}{r}15 \\
6\end{array}$ & $\begin{array}{l}1 \\
7\end{array}$ & $\mathrm{n} / \mathrm{a}$ & $\begin{array}{l}\text { COL4 } \\
\text { A1 }\end{array}$ & $\begin{array}{l}\text { c. } 24 \\
40 \mathrm{G} \\
>\mathrm{A}\end{array}$ & $\begin{array}{l}\text { p.(Gly } \\
\text { 814Ar } \\
\text { g) }\end{array}$ & Het & $\begin{array}{l}\text { NM } 00 \\
184 \overline{5.5}\end{array}$ & & 0 & 0 & $\begin{array}{l}26 \\
, 5\end{array}$ & D & D & D & 3 & $\mathrm{SVD}^{8}$ & $\begin{array}{l}\text { Nove } \\
1\end{array}$ & Yes & Yes & Yes \\
\hline
\end{tabular}




\begin{tabular}{|c|c|c|c|c|c|c|c|c|c|c|c|c|c|c|c|c|c|c|c|c|}
\hline $\begin{array}{r}15 \\
6 \\
\end{array}$ & & & $\begin{array}{l}\text { PSEN } \\
2 \\
\end{array}$ & $\begin{array}{l}\text { c. } 53 \\
\mathrm{C}>\mathrm{T}\end{array}$ & $\begin{array}{l}\text { p. } \\
\text { (Thr1 } \\
\text { 8Met) }\end{array}$ & Het & $\begin{array}{l}\text { NM_00 } \\
0447.2\end{array}$ & \begin{tabular}{|l|} 
rs143 \\
0618 \\
87 \\
\end{tabular} & $\begin{array}{l}0.00 \\
002\end{array}$ & 0 & 29 & D & D & D & 3 & $\mathrm{AD}^{41}$ & $\begin{array}{l}\text { Nove } \\
1\end{array}$ & No & Yes & No \\
\hline $\begin{array}{r}16 \\
0 \\
\end{array}$ & $\begin{array}{l}5 \\
6\end{array}$ & $\mathrm{n} / \mathrm{a}$ & $\begin{array}{l}\mathrm{COL} 4 \\
\mathrm{~A} 2\end{array}$ & $\begin{array}{l}\text { c. } 42 \\
91 \mathrm{C} \\
>\mathrm{T} \\
\end{array}$ & $\begin{array}{l}\text { p.(Arg } \\
1431 \mathrm{C} \\
\text { ys) }\end{array}$ & Het & $\begin{array}{l}\text { NM_00 } \\
1846.3\end{array}$ & \begin{tabular}{|l|} 
rs 139 \\
1249 \\
60 \\
\end{tabular} & $\begin{array}{l}0.00 \\
0007\end{array}$ & 0 & $\begin{array}{l}14 \\
, 1 \\
1 \\
\end{array}$ & $\mathrm{P}$ & D & D & 3 & $\mathrm{SVD}^{8}$ & $\begin{array}{l}\text { Nove } \\
1\end{array}$ & Yes & Yes & No \\
\hline $\begin{array}{r}18 \\
4 \\
\end{array}$ & $\begin{array}{l}7 \\
1 \\
\end{array}$ & $\mathrm{n} / \mathrm{a}$ & NPPA & $\begin{array}{l}\text { c. } 37 \\
7 \mathrm{G}> \\
\text { A }\end{array}$ & $\begin{array}{l}\text { p.(Arg } \\
126 \mathrm{Gl} \\
\mathrm{n})\end{array}$ & Het & $\begin{array}{l}\text { NM_00 } \\
6172.4\end{array}$ & $\begin{array}{l}\text { rs } 180 \\
3268\end{array}$ & \begin{tabular}{|l|}
0.00 \\
0075 \\
92 \\
\end{tabular} & $\begin{array}{l}0.00 \\
0642 \\
7\end{array}$ & $\begin{array}{l}19 \\
, 6 \\
9 \\
\end{array}$ & D & $\mathrm{N}$ & D & 3 & Atrial fibrillation familial ${ }_{33}^{32,}$ & $\begin{array}{l}\text { Nove } \\
1\end{array}$ & Yes & No & No \\
\hline $\begin{array}{r}20 \\
4\end{array}$ & $\begin{array}{l}6 \\
9\end{array}$ & $\mathrm{n} / \mathrm{a}$ & $A P P$ & $\begin{array}{l}c .17 \\
95 \mathrm{G} \\
>\mathrm{A}\end{array}$ & $\begin{array}{l}\text { p.(Glu } \\
\text { 599Ly } \\
\text { s) }\end{array}$ & Het & $\begin{array}{l}\text { NM_00 } \\
0484.3\end{array}$ & \begin{tabular}{|l|} 
rs140 \\
3047 \\
29 \\
\end{tabular} & $\begin{array}{l}0.00 \\
149\end{array}$ & $\begin{array}{l}0.00 \\
836\end{array}$ & $\begin{array}{l}20 \\
, 5\end{array}$ & D & D & D & 3 & $\mathrm{AD}^{17}$ & $\begin{array}{l}\text { PD, } \\
\text { LBD } \\
18-20\end{array}$ & Yes & No & No \\
\hline $\begin{array}{r}23 \\
5 \\
\end{array}$ & $\begin{array}{l}5 \\
6 \\
\end{array}$ & $\mathrm{n} / \mathrm{a}$ & $\begin{array}{l}\text { NOTC } \\
\text { H3 } \\
\end{array}$ & $\begin{array}{l}\text { c. } 21 \\
49 \mathrm{C} \\
>\mathrm{T} \\
\end{array}$ & $\begin{array}{l}\text { p.(Arg } \\
717 \mathrm{Cy} \\
\text { s) } \\
\end{array}$ & Het & $\begin{array}{l}\text { NM_00 } \\
0435.2\end{array}$ & \begin{tabular}{|l|} 
rs144 \\
1632 \\
98 \\
\end{tabular} & $\begin{array}{l}0.00 \\
0036\end{array}$ & 0 & $\begin{array}{l}29 \\
3\end{array}$ & D & D & $\mathrm{T}$ & 3 & CADASIL1 $^{5}$ & $\begin{array}{l}\text { Nove } \\
1\end{array}$ & Yes & Yes & No \\
\hline $\begin{array}{r}37 \\
9 \\
\end{array}$ & $\begin{array}{l}7 \\
0 \\
\end{array}$ & $\begin{array}{l}\mathrm{Ye} \\
\mathrm{s}\end{array}$ & $\begin{array}{l}\text { HTRA } \\
1 \\
\end{array}$ & \begin{tabular}{|l} 
c. 96 \\
$1 \mathrm{G}>$ \\
$\mathrm{A}$ \\
\end{tabular} & $\begin{array}{l}\text { p.(Ala } \\
321 \mathrm{Th} \\
\text { r) }\end{array}$ & Het & $\begin{array}{l}\text { NM_00 } \\
2775.4\end{array}$ & \begin{tabular}{|l|} 
rs5887 \\
7764 \\
49 \\
\end{tabular} & $\begin{array}{l}0.00 \\
0081\end{array}$ & $\begin{array}{l}0.00 \\
089\end{array}$ & 34 & D & D & D & 3 & CARASIL $^{6}$, CADASIL2 $^{7,16}$ & $\begin{array}{l}\text { CAR } \\
\text { ASIL } \\
15\end{array}$ & Yes & No & No \\
\hline $\begin{array}{r}37 \\
9\end{array}$ & & & $\begin{array}{l}\text { COL4 } \\
\text { A1 }\end{array}$ & \begin{tabular}{|l|} 
c. 40 \\
1C> \\
T
\end{tabular} & $\begin{array}{l}\text { p.(Pro } \\
\text { 134Le } \\
\text { u) }\end{array}$ & Het & $\begin{array}{l}\text { NM_00 } \\
1845.5\end{array}$ & \begin{tabular}{|l|} 
rs140 \\
5178 \\
31 \\
\end{tabular} & $\begin{array}{l}0.00 \\
042\end{array}$ & $\begin{array}{l}0.00 \\
2867\end{array}$ & $\begin{array}{l}22 \\
, 8\end{array}$ & D & D & $\mathrm{T}$ & 3 & $\mathrm{SVD}^{8}$ & $\begin{array}{l}\text { Nove } \\
1\end{array}$ & Yes & No & No \\
\hline
\end{tabular}

ACMG variant classification ${ }^{13}(5=$ pathogenic, $4=$ likely pathogenic, $3=$ variant of unknown significance, $2=$ likely benign, $1=$ benign $)$. 
CADD, Combined Annotation Dependent Depletion ${ }^{42}$, algorithm for scoring the deleteriousness of variants $(\geq 10=$ belongs to $10 \%$ most deleterious variants in the human genome, $\geq 20$ = belongs to $1 \%$ most deleterious variants in the human genome).

Polyphen2, MutationTaster, SIFT pathogenicity prediction tools (Polyphen2, $\mathrm{D}=$ damaging, $\mathrm{P}=$ possibly damaging, $\mathrm{B}=$ benign; MutationTaster, $\mathrm{D}=$ disease causing, $\mathrm{N}=$ polymorphism; SIFT, $\mathrm{D}=$ damaging, $\mathrm{T}=$ tolerated)

AAO, age at onset; AD, Alzheimer's disease; FTLD, frontotemporal lobar degeneration; het, heterozygous; LBD, Lewy Body Dementia; n/a, no information available; PD, Parkinson's disease 
365 patients with suspected CADASIL and screened negative for NOTCH3 mutations p.Arg133Cys and p.Arg182Cys

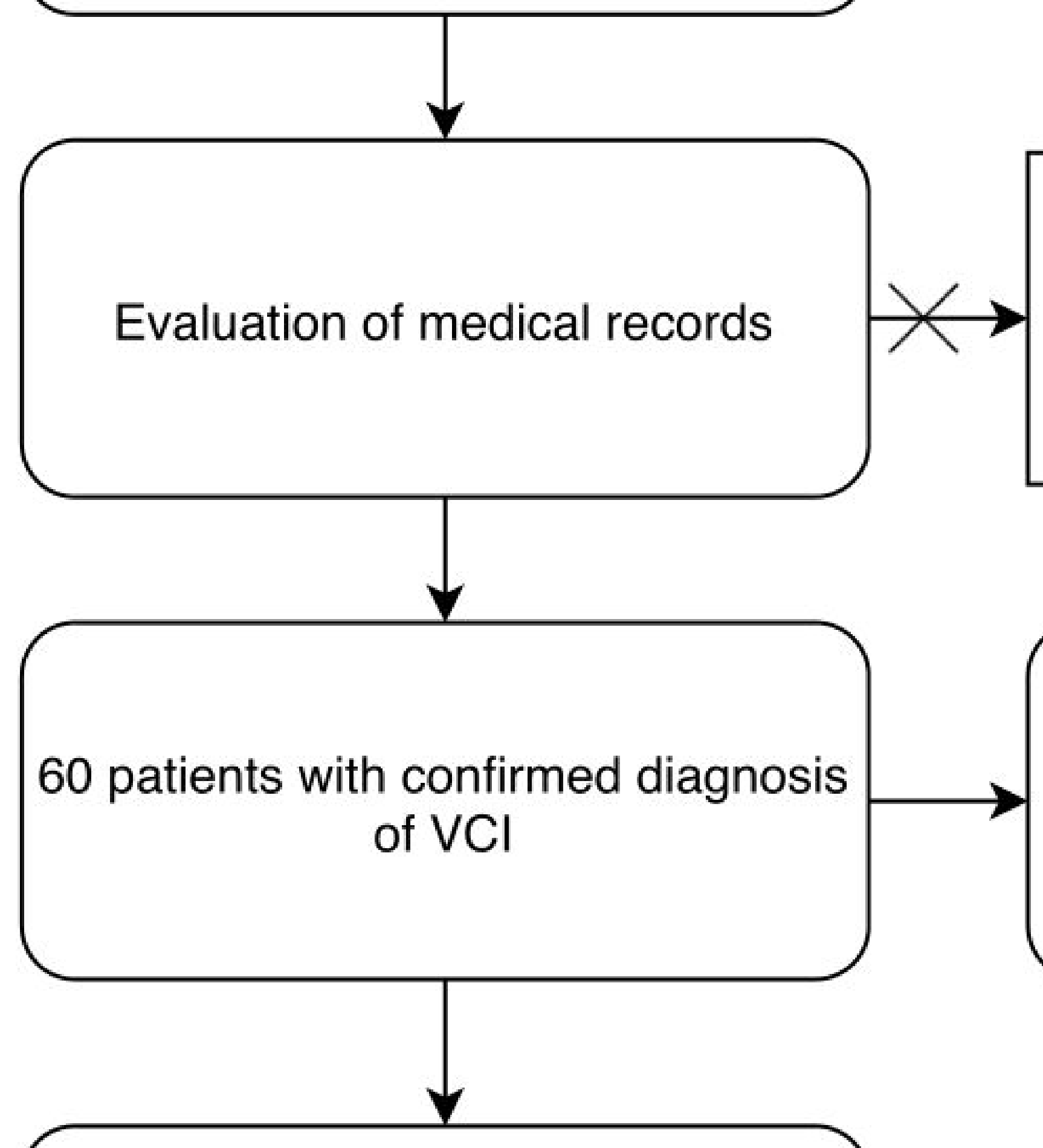

305 patients with other diagnoses or with unclear clinical picture

Sequence analysis of the miR-29 microRNA binding site in the 3'UTR of COL4A1

\section{5 patients selected for WES}

Inclusion criteria:

- $\mathrm{VCl}$ with white matter changes in MRI

- AAO up to 75 years and/or family history of dementia or stroke 
Whole-exome sequencing of Finnish patients with vascular cognitive impairment

\section{SUPPLEMENTAL MATERIAL}

\section{Supplemental Methods}

Whole-exome sequencing

Library preparation, Data processing, Variant calling and Annotation

Exome sequencing libraries were prepared using the Nextera Exome Capture Kit (Illumina) or the SureSelect Exome Capture Kit v4 (Agilent). Sequencing was performed on NextSeq550 or HiSeq2500 systems (Illumina) with 75-100 bp paired-end reads. Coverage of 30x was achieved for all samples and exome processing was accomplished following the GenomeAnalysisTK (GATK) best practices v3 ${ }^{1}$. In short, alignment was performed with the Burrows-Wheeler Aligner (bwa-mem) v0.7.12 against the hg19 genome assembly, samblaster v0.1.21 identified duplicates and base recalibration was achieved with GATK v3.8-1, excluding known sites. Variant Quality Score Recalibration (VQSR) was applied to variants which were excluded if they did not reach a 0.99 score ${ }^{2,3}$. Finally, data was annotated with snpEff $\mathrm{v} 4.2^{4}$ and dbNSFP $\mathrm{v} 2.9^{5}$ 


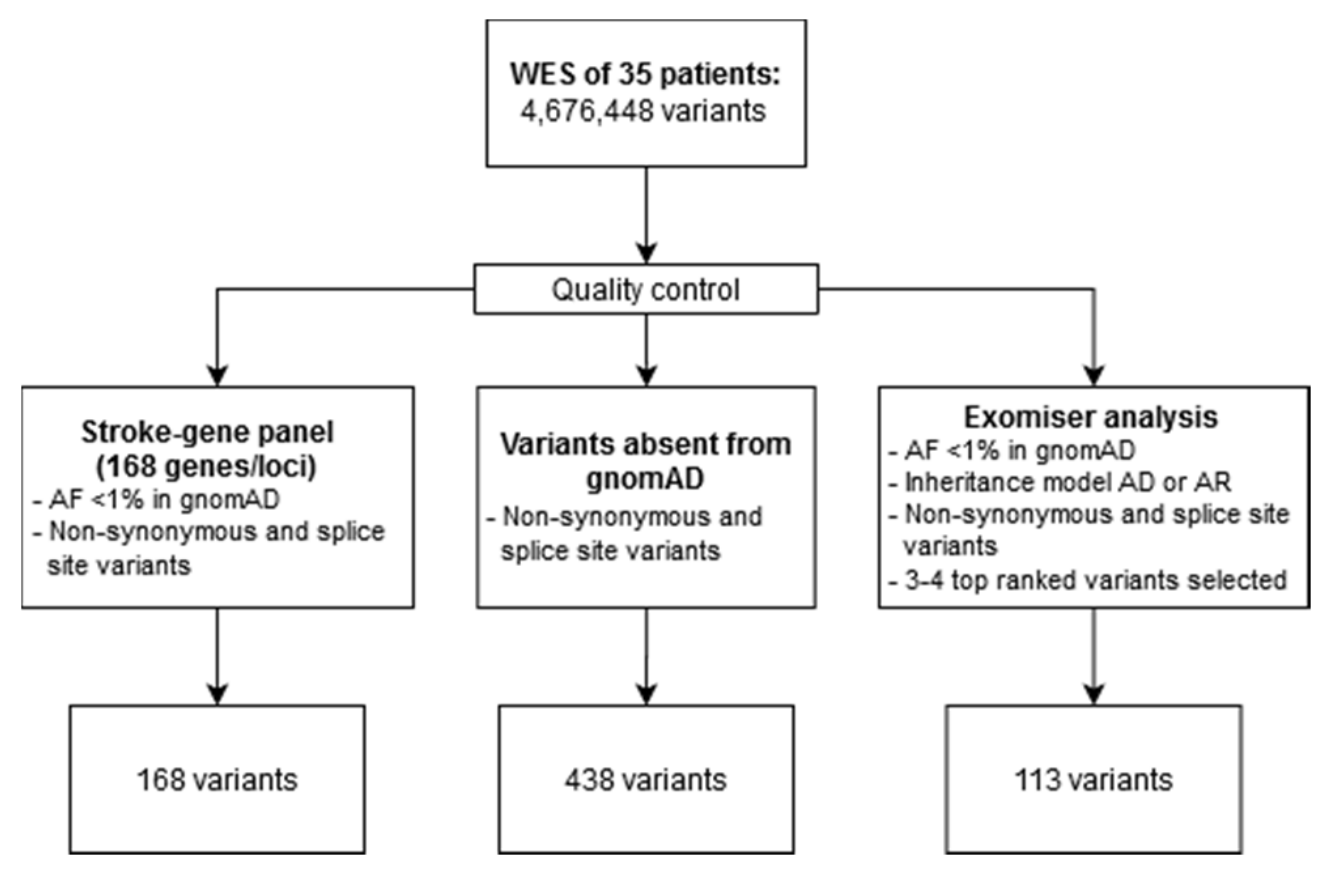

Supplemental Figure 1. The workflow of the WES data analysis.

$\mathrm{AD}$, autosomal dominant; AF, allele frequency; AR, autosomal recessive; WES, wholeexome sequencing 


\section{References}

1. McKenna A, Hanna M, Banks E, Sivachenko A, Cibulskis K, Kernytsky A, et al. The Genome Analysis Toolkit: a MapReduce framework for analyzing next-generation DNA sequencing data. Genome Res. 2010; 20: 1297-1303.

2. DePristo MA, Banks E, Poplin R, Garimella KV, Maguire JR, Hartl C, et al. A framework for variation discovery and genotyping using next-generation DNA sequencing data. Nat.Genet. 2011; 43: 491-498.

3. Van der Auwera, G. A., Carneiro MO, Hartl C, Poplin R, Del Angel G, LevyMoonshine A, et al. From FastQ data to high confidence variant calls: the Genome Analysis Toolkit best practices pipeline. Curr.Protoc.Bioinformatics. 2013; 43: 11.10.111.10.33.

4. Cingolani P, Platts A, Wang le L, Coon M, Nguyen T, Wang L, et al. A program for annotating and predicting the effects of single nucleotide polymorphisms, SnpEff: SNPs in the genome of Drosophila melanogaster strain w1118; iso-2; iso-3. Fly (Austin). 2012; 6: 80-92.

5. Liu X, Jian X, Boerwinkle E. dbNSFP v2.0: a database of human non-synonymous SNVs and their functional predictions and annotations. Hum.Mutat. 2013; 34: 2393. 


\section{Supplemental Table Legends}

Supplemental Table I. Characteristics of the initial cohort of 365 patients studied, based on medical records. Patients were referred for diagnostic testing for NOTCH3 in the Department of Medical Genetics of Turku University Hospital. All the patients were negative for the screening of the most common variants affecting function in NOTCH3 in Finland (p.Arg133Cys and p.Arg182Cys).

Supplemental Table II. The stroke-gene panel results.

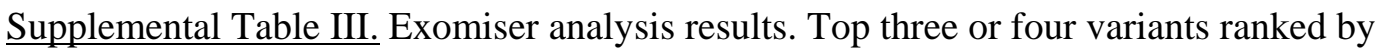
Exomiser.

Supplemental Table IV. All novel variants detected by WES. The variants were absent from the gnomAD database (v2.1.1). 